\title{
The Training-of-Trainers Initiative and the Advancement of Economics Education in South African Schools: The Case of Free State FET Schools
}

\author{
Micheal M van Wyk \\ Department of Curriculum and Instructional Studies, \\ School of Teacher Education, College of Education, \\ University of South Africa, Pretoria \\ vwykmm@unisa.ac.za
}

\section{Doi:10.5901/mjss.2013.v4n13p711}

\section{Abstract}

From the onset, blogs served as personal social networking tools. More recently, blogs have facilitated the formation of online social networked communities and have thus expanded to more extensive uses in education. This paper explore the use of blogs to foster e-learning communities in empowering and supporting Post Graduate Certificate of Education (PGCE) students, who were learning to teach Economics education in open distance learning (ODL) environments. A "blog" for Economics education subject didactics students was created during their teaching practice period. Student teachers were encourage to post their views on the "Econblog" as a communicative platform to critically reflect on their learning processes as well sharing teaching practice experiences to enhance professional growth. Data collected was qualitative in nature, consisting of student teachers' posting reflections and comments on the "blog". Findings indicated that blog" as an e-learning tool promoted good relationships amongst student communities, support by exchanging ideas and information on teaching practice, provide opportunities to interact, entering into dialogue and reflective practice. Students alluded to challenges faced during teaching practice placements.

\section{Introduction}

"Education is the most powerful weapon which you can use to change the world." Nelson Mandela

South Africa is going through several education reforms in order to prepare more learners for challenges and success in the 21st century and beyond. A key to the success of the reforms is the quality of teachers and their teaching methods (Shiller, 2010, van Wyk, 2012). Several research studies indicatedthat teachers tend to rely heavily on traditional forms of teaching highly focused on school examinations, hence, the success of the reforms depends in part on changing how teachers carry out their pedagogical role (van Wyk, 2007; Gao \& Watkins, 2002). Research in South African schools has shown that unless teachers realize the need for a new approach to teaching and challenge their traditional views of the nature of learning and teaching, real change is unlikely to occur (van Wyk, 2012;Gao, 1992; Gao et al., 1989). As Van Wyk, Alexander \& Moreeng (2010) claimed: "Changing the conceptions of teaching and schooling is now the key to improving students' quality" (p. 9).Thus changing how teachers conceive of teaching appears to be urgent in the current South African educational context. However, first it is important to understand teachers' current conceptions of effective teaching for excellence. The question of what constitutes effective teaching has been researched for decades. However, changes in assessmentstrategies, the availability of newer statistical methodologies,and access to large databases of student achievement information, as well as the ability to manipulate these data, merita careful review of how effective teachers are identified andhow their work is examined. A better understanding of whatconstitutes teacher effectiveness has significant implicationsfor decision making regarding the preparation, recruitment, compensation, inservice professional development, and evaluationof teachers' praxis. Recently, teachers have begun to emphasize the importance of linking teachereffectiveness to various aspects of teacher education and districtor school personnel administration, including:

- identifying the knowledge and skills initial teacher and in-service teachers need to be effective change agents;

- teachers need,recruiting and inducting potentially effective teachers,

- designing and implementing professional development,

- conducting valid and credible evaluations of teachers, and 
- dismissing ineffective teachers while retaining effective ones (van Wyk 2010; Darling-Hammond \& Bransford, 2005;

This type of alignment is receiving increasing attention as animportant means for providing quality education to all studentsand improving school performance. To achieve these imperatives, the National Policy Framework for Teacher Education and Development in South Africa (National Department of Education 2007), stated as a policy directive the right to quality education for all in South Africa as a democratic right without limitation, and schooling is described as a public good in which teachers are the key agents for change. This policy imperative demand from teachers, as evident in the seven roles set out in terms of the Norms and Standards for Educators, is also quite impressive and is expected to have a significant impact on teacher training and curriculum development initiatives in all school curricula and also relate to economics education. A profound change in teacherpractices is called for, which would entail theestablishment of sustainable enabling teachingand learning environments and conditions whichpromote fundamental and critical engagement ina transformative education system. It is recommendedthat professional teachers should beregarded as the essential resource of the educationsystem, and that programmes for teachereducation and training should reinforce the professional competencies and commitments ofteachers, as stipulated in the Norms and Standards for Educators policy document (NDE 1997).In South Africa, this can be seen as a response tothe government's call for a more socially responsiveeducation system. Within this legislation,it is suggested that schools and universities in particular, should be more responsive tolocal and national needs when addressing socialproblems such as poverty, unemployment, crime, and the lack of health and associated facilities. Walstad and Rebeck (2001) mentioned that a viable education system with committed, competent and confident teachers is a primary condition for achieving quality education for all, especially within the Curriculum and Assessment Policy Statement (CAPS) for South African schools.

In view of the latter, the primary objective of thisinaugural lecture is to investigate economics teachers' perceptions of the Training-of-Trainers initiative (ToT) as a driver for professional empowerment in Free State Further Education and Training (FET) schools.

To achieve this objective, the following research questions are formulated:

- What is economics education and why is it important to promote this phenomenon in South African schools?

- What constitutes the Training-of-Trainers project and what enabling theories were identified which foreground this training initiative as a case study in Free State FET schools?

- What were the main findings of this study and what recommendations were formulated for further investigation as a mean to strengthen and promote economics education in schools?

In the next paragraphs, economics education is conceptualized and the importance of this phenomenon is discussed. Secondly, several theories were identified which underpin the Training-of-Trainers initiative as a case study in Free State FET schools. Furthermore, the results of the investigation are explained. Finally, conclusions were highlighted and recommendations formulated for further investigation into economics education as an important school subject.

\section{Advancing Economics Education In South African Schools}

\subsection{Conceptualizing of Economic education as catalyst for economic empowerment}

Economics education is a field within economics that focuses on two main themes: 1) the current state of, and efforts to improve the economics curriculum, learner support materials and pedagogy used to teach economics at all educational levels; and 2) research into the effectiveness of alternative instructional techniques in economics, the level of economic literacy of various groups, and factors that influence the level of economic literacy. Economics education is distinct from economics of education, which focuses on the economics of the institution of education. Economic education focuses on the scholarship of teaching and learning economics as a subject. It encompasses the content to be taught (what-subject content knowledge), different teaching methods (how-pedagogical content knowledge), designing of applicable assessmentpractices (why-purpose of using assessment tools/strategies), and information of general interest to teachers of economics in primary, secondary to undergraduate studies. The purpose of economic education is to create future responsible citizens, effective decision-makers and voters for change. Economic education is a very crucial subject that many of our nation's schools tend to overlook. The importance of economic education goes far beyond the goal of improving an understanding of the basic principles of supply and demand and the workings of the economy. Economics can be taught by generating new knowledge with the help of exposing students to real-life learning environments and experiences. Students develop perceptions of their economic world at an early age, which, as they progress through the educational process, develop into attitudes and opinions about the subject of economics. Intended or not, teachers 
influence the direction of attitude development. My view is that we must equipped our learners with effective money management skills and provide an understanding of how our ever-changing, fast-paced global economy works to avoid future global economic crisis.

Walstad and Rebeck (2001) concurred and argues that economic knowledge is vital important for economic growth and development. The authors alluded that:

..[the] opportunity for improving the economic understanding of all youth occurs in high school. ...only about 63 percent of all high school graduates enroll in colleges and universities, and among those who do, only about 40 percent take even one college course in economics. For many students, the economics that they learn in high school will be all the economics they ever study (p.195).

The authors further emphasized that despite these gains; knowledge of economics by secondary school learners is relatively weak, suggesting that work remains in raising public literacy in a subject that is of central importance for citizens in many aspects of their lives. The importance of economics education goes far beyond the goal of improving an understanding of the basic principles of supply and demand and the workings of our economy. Learners develop perceptions of their economic world at an early age, which, as they progress through the educational process, develop into attitudes and opinions about the subject of economics. Intended or not, teachers influence the direction of attitude development (Walstad, 1992, 1997). By finding ways to teach learners more about economics, teachers are contributing to improved attitudes toward the subject. By teaching basic economic concepts and applying them to classroom discussions of economic issues and institutions, teachers are not indoctrinating learners, but providing a knowledge foundation for more informed learner opinions and decision making on vital issues. The more economics concepts learners know, the more they like and value the subject and the more information they have about economic issues. Learners who do not get the opportunity to learn economics and increase their economic understanding will probably never take much interest in the subject or in their economic world.

\subsection{Knowledge Is Power: The Importance of Economics Education}

Economic education is extremely important because it is vital to the future health of our nation's economy. But why is economic education needed? Why can we not rely on the truths of economics being recognized by the intelligent public without deliberate, organized effort at public enlightenment? Economic education, aiming to enlighten the intelligent lay public to these significant-but still counter-intuitive-implications of economics, surely has a valuable role to play. Let us however now turn to the second of the reasons we have identified (as responsible for the need for economic education). Economic understanding does not call for sophisticated technical prowess. It does, however, require appreciation for a way of looking at human actions and of social interaction, which many at first find rather strange and unfamiliar. Economic understanding requires one to see the "objects" with which economic activity is concerned-the money, the natural resources, the capital equipment, the flows of half-finished goods, the fully produced goods ready for delivery to the consumer-from a subtly different perspective from that to which the layperson has been accustomed. Take, for example, the simple act of exchange. To the untrained eye, an episode of market exchange is seen as one in which an exchange of objects, presumably of equal value, occurs. When I buy a meal for R120, I have given up a R120 bill for food and service having a market value of R120. For the economist this episode is seen in an entirely different light. For me the meal was subjectively valued as being more important than the R120 bill that I was asked to surrender for the meal. For the owner of the establishment that sold me the meal, its value was lower than that of the prospective R120 he/she hoped to receive from me. So that this simple episode of exchange must have meant, in the prospective judgments of both the consumer and the vendor, that new, additional value was being created by this exchange. This elementary insight, so foundational to economic reasoning and understanding, is strange and unfamiliar to the world of commerce and of everyday activity.

The global economy has changed many of the ways we live and do business. It is critical that we equip our learners and students, the workforce of tomorrow, with an understanding of how the economy works, and knowing how it affects everything from money management to small business to large corporations. A foundation in economic and financial literacy will inspire entrepreneurship, innovation, and prepare students to successfully adapt to a dynamic marketplace. We need as a matter of urgent, introduce key economic and personal finance concepts throughout grades 7-12 not as it is now grade 7-9 and then as an elective subject but a compulsory school subject, including:

- The ability to analyze, reason, and apply good decision-making skills 
- Recognizing that resources are limited and that every choice has an opportunity cost (making one choice means giving up another)

- How to buy, save, and invest wisely-for themselves and our future economy

- How being an effective employee contributes to a company's success-and their own

- Recognizing that they are their own best resource - education and skill-building is an important way for students to invest in themselves, their future, and their community

In summation, economics is about choice and the impact of our choices on each other. It relates to every aspect of our lives, from the decisions we make as individuals or families to the structures created by governments and firms.

\section{The Case of Free State Fet Schools: The Training-of-Teachers Initiative}

\subsection{Teacher efficacy construct: Lewis et al. (1999)}

Effectiveness is an elusive concept to define when we consider the complex task of teaching and the multitude of contexts in which teachers work. In discussing teacher preparation and the qualities of effective teachers, Dickie (2006) aptly noted that "teacher quality is a complex phenomenon, and there is little consensus on what it is or how to measure it" (p.3). In fact, there is considerable debate as to whether we should judge teacher effectiveness based on teacher inputs (e.g., qualifications), the teaching process (e.g., instructional practices), the product of teaching (e.g., effects on student learning), or a composite of these elements.

Teacher efficacy has emerged as an important construct in teacher education over the past two decades in the social science and humanities. Wheatley (2005) defined the concept as:... "teachers' beliefs in their ability to actualize the desired outcomes" (p.748). Teacher efficacy has emerged as an important construct and teachers' beliefs in their ability to actualize the desired outcomes for their students. Teacher efficacy has been linked to teacher effectiveness and appears to influence students in their academic achievements (Dickie 2006; Wheatley 2005; Goddard et al. 2000). Teacher efficacy has been linked to teacher effectiveness and appears to influence students in their achievement, attitude and affective growth. Scholars have shown that teacher efficacy has positive effects on teacher effort and persistence in the face of difficulties (Dickie 2006; Soodak and Podell 1993), professional commitment (TschannenMoran et al. 2001), Coladarci 1992), student motivation (Midgley et al. 1989), and openness to new methods in teaching and positive teacher behaviour (Ghaith and Shaaban 1999). Moreover, Ghaith and Yaghi (1997) mentioned that in addition, teachers with a high sense of efficacy are more likely to use student-centred teaching strategies, while lowefficacious teachers tend to use teacher-directed strategies, such as didactic lectures and reading from textbooks (Dickie 2006). Thus, the importance of teacher efficacy is well established. Teachers' sense of efficacy and reforms in curriculum has many common points (Goddard et al. 2000). The changes teachers apply to their practices and adaptation to innovations require that they have a high sense of efficacy. Nevertheless, while both the implementation of reform in teacher education and teacher efficacy beliefs have been studied in depth over the years, there have been few research studies completed on the possible connection between the two. In this study, teacher efficacy is considered the basis for enhancing student learning, achieving school effectiveness, improving teacher evaluation and designing and improving the quality of the Training-of Trainers programmes (van Wyk \& Alexander, 2010).

\subsection{Social Cognitive Learning theory: Albert Bandura (1997)}

Social cognitive learning theory highlights the idea that much of human learning occurs in a socialenvironment. In this study, Economics teachers by observing others, they acquire knowledge of rules, skills, strategies, beliefs, andattitudes which empowered to plan enabling classrooms. Individual teachers and groups also learn about the usefulness and appropriateness of behaviors by observing models and the consequences of modelled behaviors and they act in accordance with their beliefsconcerning the expected outcomes of actions during the ToT initiative.The social learning theory proposed by Albert Bandura has become perhaps the most influential theory of learning and development. While rooted in many of the basic concepts of traditional learning theory, Bandura believed that direct reinforcement could not account for all types of learning.His theory added a social element, arguing that people can learn new information and behaviors by watching other people. In this research, facilitators demonstrated several lessons to FET Economics teachers by role-playing economic concepts during Tot project. This type of teaching method, role playing is known as observational learning (or modeling). According Bandura, this type of learning can be used to explain a wide variety of behaviors.Moreover, there are three core concepts at the heart of social learning theory. According to this theory, people 
can learn through observation. Secondly, the idea of internal mental capability is an essential part of this process. Finally, this theory recognizes that just because something has been learned, it does not mean that it will result in a change in behavior.

\subsection{Transformative Learning Theory: Jack Mezitow (1991)}

Mezirow(1991)posit that transformative learning is the process of effecting change in a frame of reference. The author argue that adults [in this case FET Economics teachers] have acquireda coherent body of experience-associations, concepts, values, feelings, conditionedresponses-frames of reference that define their life world. Frames ofreference[of FET Economics teachers] are the structures of assumptions through which they related and understand their experiences throughout this project. They selectively shape and delimit expectations, perceptions, cognition,and feelings of individuals and group members of the ToT project. They set a "line of action." Once set, they automaticallymove from one specific activity (mental or behavioral) to another learning unit in the Economics Modular manual. When circumstances permit, transformative learners move towarda frame of reference that is more inclusive, discriminating, self-reflective, andintegrative of experience.A frame of reference encompasses cognitive, conative, and emotional components, and is composed of two dimensions: habits of mind and a point of view.Habits of mind are broad, abstract, orienting, habitual ways of thinking, feeling,and acting influenced by assumptions that constitute a set of codes. These codesmay be cultural, social, educational, economic, political, or psychological. Habitsof mind become articulated in a specific point of view-the constellation of belief,value judgment, attitude, and feeling that shapes a particular interpretation.An example of a habit of mind is ethnocentrism, the predisposition toregard others outside one's own group as inferior. A resulting point of view isthe complex of feelings, beliefs, judgments, and attitudes we have regardingspecific individuals or groups (van Wyk, Alexander \& Moreeng, 2010). Frames of reference are primarily the result of cultural assimilation andthe idiosyncratic influences of primary caregivers. Habits of mind are moredurable than points of view. In this case, facilitators employ discussion forums and debriefing sessions to stimulate critical thinking. Most of the participants express different points of view which were subject to continuing change as some of them reflect on either the content or process by which they solve problems to identify the need to modify assumptions. This happens whenever participants in this study try tounderstand actions that do not work as the way they anticipated. Perhaps, points of view are more accessible to awareness and to feedback from others. According to Mezirow (1991), we transform our frames of reference through critical reflection on theassumptions upon which our interpretations, beliefs, and habits of mind orpoints of view are based. We can become critically reflective of the assumptionswe or others make when we learn to solve problems instrumentally orwhen we are involved in communicative learning. We may be critically reflectiveof assumptions when reading a book, hearing a point of view, engaging intask-oriented problem solving (objective reframing), or self-reflectively assessingour own ideas and beliefs (subjective reframing). According to Mezirow (1998), self-reflection can lead to significant personal transformations. Critically explored assumptions may be in the autobiographical contextof a belief, or they may be supporting a social, cultural, economic, political,educational, or psychological system. Transformations in frames of referencetake place through critical reflection and transformation of a habit of mind, orthey may result from an accretion of transformations in points of view.

From the perspective of transformation theory, the nature of adult learningimplies a set of ideal conditions for its full realization that may serve as standardsfor judging both the quality of adult education and the socio-political conditions that facilitate or impede learning. From the perspective of transformationtheory, there are ideal conditions for the full realization of adultlearning; these conditions can serve as standards for judging both the qualityof adult education and the socio-political conditions that facilitate or impedelearning. The position here is that there is an inherent logic, ideal, and purposein the process of transformative learning. The process involves transformingframes of reference through critical reflection of assumptions,validating contested beliefs through discourse, taking action on one's reflectiveinsight, and critically assessing it. In this study, the understanding of the nature of significantadult learning provides the ToT facilitators with a rationale for selectingappropriate educational practices [demonstrations, role playing, discussion forums, group work, cooperative learning methods, think-pair-share strategy and actively resisting social and culturalforces that distort and delimit adult learning.

\subsection{Communities of Practice theory: Lave and Wenger (1991)}

Lave and Wenger (1991) define "communities of practice are groups of people who share a concern or a passion for something they do and learn how to do it better as they interact regularly." This theory underpin this study because the process of social learning that occurs when FET Economics teachers who participated in the ToT project have a common 
interest in the subject of economics, sharing ideas and strategies, determine solutions, and build innovations. Economics teachers in this study demonstrated as the communities of practice (CoP) share a passion for something that they do, and who interacts regularly to learn how to do it better. A CoP has an identity defined by a shared domain of interest; it's not just a network of Economics teachers. A necessary component is that Economics teachers interact and engage in shared activities, help each other, and share information with each other. They build relationships that enable them to learn from each other. In this way, merely sharing the same job does not necessitate a CoP. There needs to be a practice: A CoP is not just people who have an interest in something (e.g. economics). The third requirement for a CoP is that the members are practitioners. They develop a shared repertoire of resources which can include stories, helpful tools, experiences, stories, ways of handling typical problems, etc. This kind of interaction needs to be developed over time. A conversation with a random stranger who happens to be an expert on a subject matter that interests you does not in itself make a CoP. Informal conversations held by people of the same profession (e.g. economics teachers) help share and develop a set of cases and stories that can become a shared repertoire for their practice, whether they realize it or not. Communities develop their practice through a variety of methods, including: problem solving, requests for information, seeking the experiences of others, reusing assets, coordination and synergy, discussing developments, visiting other members, mapping knowledge and identifying gaps.For Etienne Wenger, learning is central to human identity. A primary focus is learning as social participation - that is, an individual as an active participant in the practices of social communities, and in the construction of his or her identity through these communities. People continuously create their shared identity through engaging in and contributing to the practices of their communities. The motivation to become a more central participant in a community of practice can provide a powerful incentive for learning.

Figure 1. FSDoE FET Economics ToT design

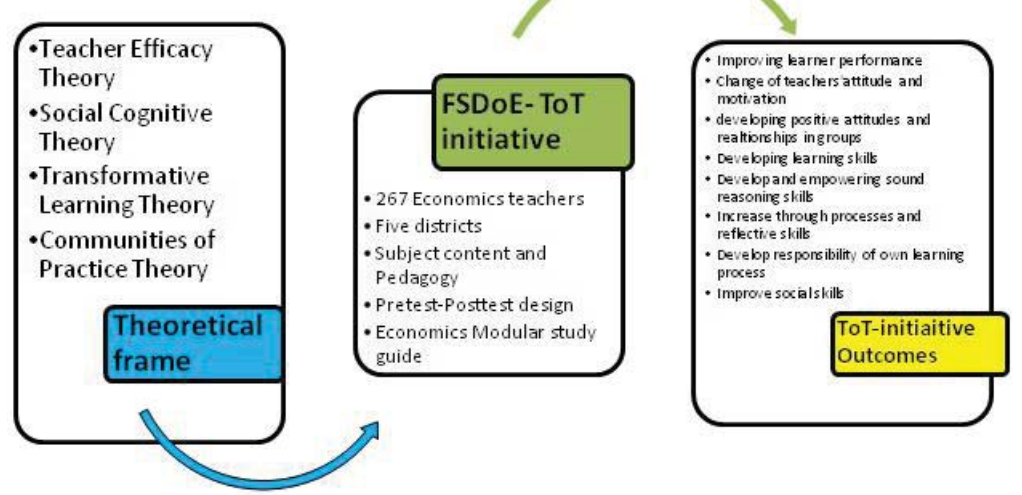

\subsection{The case of Free State FET schools: Training-of-Trainers (ToT) initiative}

\subsubsection{Purpose of the Training-of-Trainers initiative}

In 2010, all curricular outlines and guidelines covering subjects taught in South African schools were replaced by a single Curriculum and Assessment Policy Statement (CAPS) for each subject. The CAPS policy emphasizes a learner centeredness approach, and requires teachers to make a praxis paradigm shift in employing active and participative teaching methods (Department of Basic Education (DBoE) 2010). As an all-embracing policy framework, this applies also to the subject of economics. The CAPS curriculum framework establishes that learners should be encouraged to gather relevant information and to transform such information into marketable knowledge. Again, this is also a specifically requirement of the CAPS curriculum policy for economics. Traditonally, economics education has focused on the teaching and learning of economics as a subject. It encompassed the content to be taught, methods of teaching, evaluation of those methods, and information of general interest to teachers of economics at all levels, from elementary through to graduate school.However, in recent years the teacher centred approach has shown itself to be an effective teaching paradigm which also yields good results in schools. According to Van Wyk (2007), learners must be enabled to identify problems and find creative and innovative solutions to them by relating them to real-life situations.

The Training-of-Trainers initiative is a driver for teacher empowerment to deliver and employ effective teaching 
strategies to advance the subject in Free State FET schools. To achieve this purpose, it is vital to skill, educate and empower teachers in subject content knowledge (SCK) and pedagogical content knowledge (PCK) to create enabling learning environments for learners.Teachers of economics are therefore required to consider effective teaching approaches, strategies and methods in order to ensure that these objectives are achieved. By employing new approaches, strategies and methods, economics teachers can provide effective enabling teaching and learning environments in such a way as to ensure that knowledge, skills and positive attitudes are optimised among learners in their response to the socio-economic environment (van Wyk 2010).

\subsubsection{Training-of-Trainers Economics workshop}

The CEE and alumni facilitation team incorporated content and pedagogyin the workshops through different learning activities in order to assist the facilitators' classroom practice, as well as to help teachers share and organize their ideas (knowledge) with fellow peers. Five phases of the FET workshops were adopted for the ToT initiative.

\subsubsection{Selection of participants}

The workshops were hosted in the educational districts centres of Bloemfontein, Kroonstad, Welkom, Sasolburg and Harrismith. Each of the five centres administered a fourteen-day workshop for 267 subject teachers, which were conducted by faculty membersand alumni during June and September school holidays (2010-2011). Two hundred and sixty seveneconomics teachers participated in the workshops. Eligibility was limited to secondary-school-level teachers who would be teaching an economics class. Contrary to normal practice, however, the centres oversubscribed eligible applicants in order to secure enough teachers to populate the workshops. The ToT workshops were organized by SAFEFE personnel at each of the five sites.

\subsubsection{Economics topics manual and assignments}

Each workshop consisted of fourteen days of training and lesson demonstrations using an economics curriculum manual. Each local workshop followed a common agenda and timetable developed by the SAFEFE staff for implementation. The workshop topics included standard treatments of introductory market economics, microeconomics, macroeconomics, international trade (globalization) and contemporary economics issues (DoE 2009). During this phase, teachersstudied their assigned topic individually and then drew a concept map to represent the main ideas of the topic. Teachers were expected to have participated in an in-depth study of the topic before joining the expert group discussion that followed. A debriefing session was held at the beginning and end of each day. Other activities includedthirty minute economics quiz test was written at the end of each day session on each facilitated topic. The individual scores were pasted on the economics quiz table.

\subsubsection{Expert group meeting}

Teachers working on the same topic formed expert groups consisting of four to five teachers per group. During this phase, teachers shared their concept maps and discussed the main ideas of the topic with other "experts", and then refined their own concept maps. The purpose of this phase was to facilitate teachers' development of "expert knowledge" before proceeding to the next phase of the class sessions into groups.

\subsubsection{Class presentation and observations}

In order to allow teachers to demonstrate their understanding of the unit, as well as to offer the class opportunities to classify/ clarify their ideas, some groups were randomly selected to report their economics concept maps and other activities to the class as a whole. Groups were encouraged to provide feedback on the presentation and provide additional questions for teachers to discuss their concept maps in their groups. Teachers received an economics manual [included all topics for the ToT] as study material for class presentations and assignments. These manuals were compiled in accordance with unit for each session per day. Facilitators used an instructional video to present the concepts on Contemporary Economic Issuesas a unit in the manual. In this unit, activities included individual study and group presentations. Groups watch the role-playing video with a worksheet and later meet to discussion and to plan for their specific group presentation on a specific topic e.g poverty or unemployment. Teachers were also provided with 
worksheets to guide their observations and to record their results.

\section{Research Methodology}

Research paradigm: A positivist-interpretive paradigm is employed for this research study which investigates economics teachers' perceptions of the Training-of-Trainers initiative (ToT) as a driver for professional empowerment in Free State FET schools.

Research design: An exploratory, descriptive, contextual quantitative research approach was selected for the purpose of conducting this study. A pretest-posttest design was constructed, making use of three data collection instruments (Cohen et al. (2009). Classroom observation was also employed as a data collrction method during the ToT project.

Sampling: A sample of two hundred and sixty seven economics teachers $(n=267)$ in the FSDoE was selected to participate in the research study. The teachers were from the Motheo, Xhariep, FezileDabi, Lejweleputswa and Thabo Mofutsanyane education districts of FSDoE. This sample represented $74 \%$ of the economics teacher population within the five districts of FSDoE.

Data collection research instruments: The three data collection instruments were distributed to 267 Economics teacherswho participated in the ToT project. Classroom observations and semi-structured focus group interviews were conducted, recorded, transcribed, coded and thematically categorized.Three research instruments were used. Firstly, the Test of Economic Literacy (TEL), a standardised test of economics content was employed. The TEL is nationally normreferenced test used in the United States for first-year economics classes at university level (NCEE 2005). Secondly, the Economics Modular Test (EMT), which covered all six units of the seminars of the ToT project. The EMT content was macroeconomics, microeconomics, contemporary economic issues and globalization, based on the CAPS for grades 1012. Thirdly, the Attitude toward Economics education scale (ATEE) was used to measure goal orientation, self-efficacy, intrinsic motivation toward economics, and cognitive processing. The reliability of an instrument indicates the accuracy with which the sample represents the accuracy of the broader universe of responses (Cohen Mansion and Morrison 2009). This, according to Cohen et al. (2009), depends on the accuracy and precision with which the measuring instrument measures. A statistical analysis tool, the Cronbach's alpha coefficient $(p=0.7)$ was used to measure of internal consistency of the items in the three data collection instruments. Furthermore, Starborn (2006) mentions that Cronbach's alpha is an appropriate test to use to assess the internal consistency of scales that are computed from Likert items. Lastly, classroom observations [an observation sheet with specific criteria] and three focus group interviews were used during group discussions and presentation to assess the participants.

Ethical considerations: Consent was obtained from the FSDoE, school principals and FET economics teachers before the study was begun. An official FSDoE letter explaining the purpose of the study was attached to the questionnaire. The letter also highlighted the confidentiality of any results deriving from each teacher's participation. Each participant signed a consent letter.

\section{Results and Discussion}

\subsection{Teachers' Test of Economic Literacy scores regarding learning activities in ToT initiative}

Test for Economic literacy test measures the economic knowledge of the teachers as they entered theclassroom at the beginning of the academic year.The researcher used a modified TEL for the pretest-posttest design for participants. The TELcomprised $90 \%$ of standardised economic literacyquestions from the NCEE Test for EconomicLiteracy and 10\% of general South Africannewspapers' economic issues. The TEL comprisedfifty multiple-choice items which was structuredand aligned on the content of ToT manual.Teacherswere asked about their perceptions of the Test of Economic literacy learning activities in the ToT project. They were asked to fill out a questionnaire by checking responses on a four point-Likert scale (see Table 1 and Figure 2\}. 


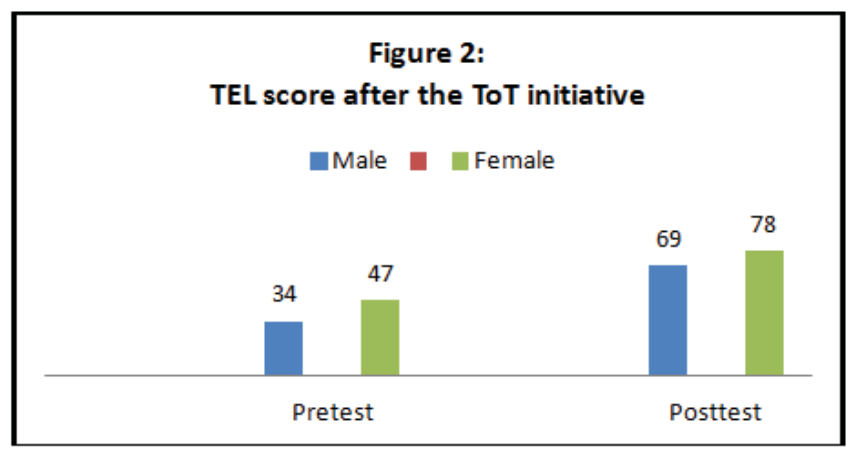

\subsection{Teachers' Economic Modular Test (EMT) scores regarding learning activities in ToT initiative}

A EMT pretest-posttest EMT was completed by all participants. Teacherswere asked about their perceptions of the Economics Modular topics learning activities in the questionnaire. They were asked to fill out the EMT questionnaire by checking responses on a four point-Likert scale. A t-test was performed on the rating scores in order to compare teachers' attitudes between the two groups. The statistical results obtained are presented in Table 1 and Figure 3.

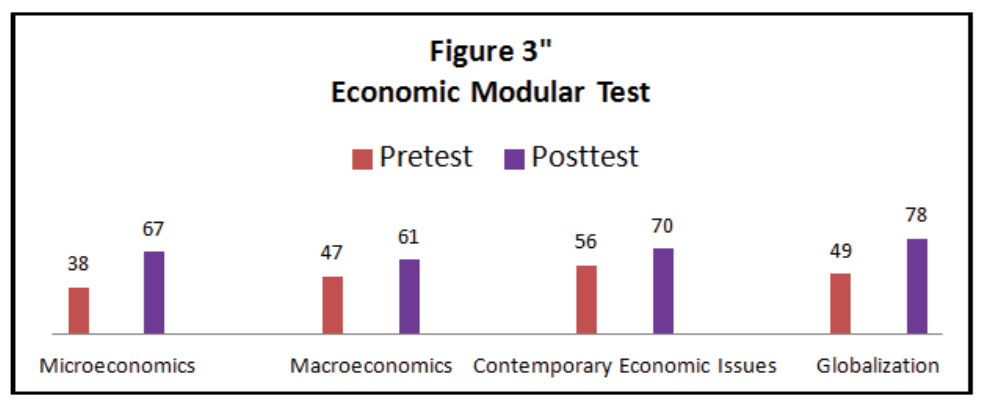

5.3 Teachers' Attitude toward Economic Education (ATEE) scores regarding learning activities in ToT initiative

The ATEE scale was used to measure participants' perceptions toward economics education during ToT project. Teachers were asked about their perceptions of their attitude towardeconomics activities in the ATEE scale. They were asked to fill out the ATEE questionnaire by checking responses on a four point-Likert scale. A t-test was performed on the rating scores in order to compare teachers' attitudes between the two groups. The statistical results obtained are presented in Table 1 and Figure 3.

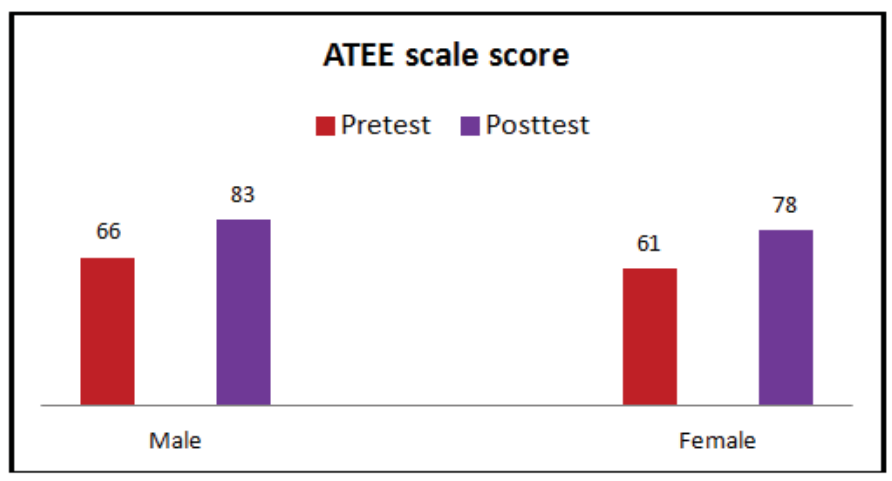


Table 1: Teachers' attitude toward learning during the TOT initiative activities $(n=267)$

\begin{tabular}{|c|c|c|c|c|c|c|}
\hline $\begin{array}{l}\text { Q- } \\
\text { no }\end{array}$ & Question statement & $\begin{array}{c}\text { Group } \\
\text { Structure }\end{array}$ & $\begin{array}{c}\text { SA \& A } \\
(\%)\end{array}$ & $\begin{array}{c}\text { D \& SD } \\
(\%)\end{array}$ & Mean & $\begin{array}{c}\mathrm{t}- \\
\text { value }\end{array}$ \\
\hline \multirow[b]{2}{*}{1} & \multirow[b]{2}{*}{$\begin{array}{l}\text { I like demonstrations of economic concepts used during } \\
\text { the workshop }\end{array}$} & Expert group & 87 & 13 & 3.3 & $3.11^{\star \star}$ \\
\hline & & $\begin{array}{l}\text { Control } \\
\text { group }\end{array}$ & 51 & 49 & 3.0 & \\
\hline \multirow{2}{*}{2} & \multirow[b]{2}{*}{$\begin{array}{l}\text { I agree that ToT activites support and help me to } \\
\text { implement in my praxis }\end{array}$} & Expert group & 51 & 49 & 3.4 & $2.73^{\star \star}$ \\
\hline & & $\begin{array}{l}\text { Control } \\
\text { group }\end{array}$ & 68 & 32 & 2.4 & \\
\hline \multirow[b]{2}{*}{3} & \multirow{2}{*}{$\begin{array}{l}\text { I like to use and application of economics concepts as } \\
\text { demonstrated in ToT initiative learning }\end{array}$} & Expert group & 68 & 42 & 3.8 & $2.97^{\star \star}$ \\
\hline & & $\begin{array}{l}\text { Control } \\
\text { group }\end{array}$ & 84 & 16 & 3.0 & \\
\hline \multirow[b]{2}{*}{4} & \multirow{2}{*}{$\begin{array}{l}\text { I like the drawing of economics concept maps as an easy } \\
\text { and fun strategy ingroup learning }\end{array}$} & Expert group & 59 & 41 & 3.7 & $2.2^{*}$ \\
\hline & & $\begin{array}{l}\text { Control } \\
\text { group }\end{array}$ & 47 & 53 & 2.9 & \\
\hline
\end{tabular}

${ }^{*} \mathrm{p}<0.05 ;{ }^{*} \mathrm{p}<0.01 \quad$ Scale: $\mathrm{SA}=$ Strongly agree, $\mathrm{A}=\mathrm{Agree}, \mathrm{D}=$ Disagree, $\mathrm{SD}=$ Strongly disagree

Overall comparison of the data in Table 1 revealed that expert teachers had positive perceptions about ToT initiative learning activities than those of control group who did not (87\% vs. 13\%). Furthermore, the t-test results revealed that there were significant differences in teachers' attitudes $(\mathrm{t}=3.11)$ between the two groups.More expert participants liked ToT initiative demonstrations of economic concepts activities (Question 1, $\mathrm{t}(100) 3.11, \mathrm{P}<0.01$ ) than did not, and considered the expert group meeting in the Jigsaw method helpful (Question 2, $t(100) 2.73, P<0.01)$. More of them also found that drawing concept maps was easier when using the handheld device (Question 4, $t(100) 2.2, P<0.05$ ).

A significant difference was found, however, between the two groups regarding whether they liked using concept maps when learning (Question 3, $\mathrm{t}(100) 2.97, \mathrm{P}<0.01)$. More teachers in the treatment group said that they liked to use concept maps (SA \& A, $59 \%$ vs. 47\%) while fewer teachers disliked it (D \& SD, $41 \%$ vs. $53 \%$ ). Classroom observations showed that economics teachers in the treatment group were more engaged and highly motivated in the learning activities than those in the control group. They were much more concerned about completing each stage of the learning activities in time, especially at the final stage, when they were required to upload their project assignments to the class notebook.

The nature of the teacher group was much like that of a typical class session - some teachers actively participated in learning activities, while others were more reluctant to get involved. Other teachers were, simply, 'recruited' by their group members. All the instructional components - the facilitator, the learning time, different methods, and the learning economics contents - were the same in the two groups.

\subsection{Test performance scores on teacher learning}

Test performance compared the learning performance outcomes of the two groups [gender] by analysing the scores achieved in the three tests (TEL, EMT, AET) completed by the teachers during the last lesson unit. In all the training units, facilitators first showed teachers an instructional digital video on the basic economic concepts of modular units [demonstration of economic lessons].

Table 2: Pretest-Posttest scores on three instruments

\begin{tabular}{|c|c|c|c|c|c|c|c|c|c|}
\hline & & & \multicolumn{2}{|c|}{ Pretest } & \multicolumn{2}{|c|}{ Posttest } & \multicolumn{4}{|c|}{ Outcome } \\
\hline Data collection instrument & $\mathrm{N}$ & $\begin{array}{c}\text { Cronbach alpha } \\
\mathrm{a}=.7\end{array}$ & EG & CG & EG & CG & $\%$ Change & $\mathrm{t}$ & Sig. (2-tailed) \\
\hline TEL & 267 & .891 & 59.5 & 48.8 & 73.1 & 58.8 & 36.0 & $3.24^{\star \star}$ & $0.000^{*}$ \\
\hline EMT & 267 & .794 & 57.1 & 56.9 & 66.3 & 73.9 & 12.3 & $2.09^{\star}$ & $0.003^{\star \star}$ \\
\hline AET & 267 & .811 & 57.5 & 50.8 & 64.1 & 75.8 & 13.0 & 1.656 & $0.000^{\star}$ \\
\hline
\end{tabular}

${ }^{\star}$ Test= 100 scoring; $\quad{ }^{*} p<0.05 ;{ }^{* \star} p<0.01 ; a=0.7 .0$ EG-Expert group ; CG-Control group

Table 2 shows a summary of the results of teachers' performance in the three tests.All three instruments met the 
Cronbach alpha reliability test $(\alpha=0.7)$. The expert group (TEL=59.5; EMT=57.1 \& AET=67.5) outperformed the control group in all three test instruments. Results indicated that there were significant differences between the pretest-posttest scores of expert and control groups. The expert group achieved higher scores as shown in the Table 2. The results are as follows: TEL, EMT \& AET, $t(267) 3.24, P<0.05 ; 2.09, P<0.01$ \& $P<0.05$. Overall the expert group of teachers $[E M T=73.5 \%$ and $A E T=75.8 \%]$ outperformed control group teachers on two of the three instruments.

\subsection{Economics teachers' interactions during group discussions}

Table 3 compares expert group interactions as regards behaviour amongst the participants and the facilitators.Several research studies conducted on the learner centredness approach have shown that interactions may take place in a variety of ways, such as exchanging resources, providing or seeking information on the project, giving and receiving feedback and encouraging group members (van Wyk 2012; Aronson 2005). To examine the interactions among teachers, the researcher has studied digital recordings of group discussions that took place during groups research project topics. The results are analyzed below.

Table 3: Group interactions during discussion groups $(n=267)$

\begin{tabular}{|c|l|c|c|c|c|c|}
\hline Question & Group behavior & Group type & $\mathrm{F}$ & $\%$ & Mean & $\mathrm{t}$-value \\
\hline \multirow{2}{*}{5} & \multirow{2}{*}{ Exchanging information } & Expert group & 44 & 22 & 3.9 & $3.14^{\star \star}$ \\
\cline { 3 - 7 } & & Control group & 33 & 16.5 & 3.2 & \\
\hline \multirow{2}{*}{6} & \multirow{2}{*}{ Receiving feedback /Support from facilitator } & Expert group & 16 & 8 & 2.1 & $2.06^{\star}$ \\
\cline { 3 - 8 } & & Control group & 20 & 10 & 2.4 & \\
\hline \multirow{2}{*}{7} & \multirow{2}{*}{ Encouraging group members } & Expert group & 40 & 21 & 3.3 & $2.09^{\star}$ \\
\cline { 3 - 7 } & & Control group & 20 & 10 & 2.4 & \\
\hline
\end{tabular}

${ }^{*} p<0.05 ;{ }^{* *} p<0.01 \quad$ Scale: $S A=$ Strongly agree, $A=A g r e e, D=$ Disagree, $S D=$ Strongly disagree

The percentage figures in Table 3 were calculated by dividing the frequency [of interaction?] by the total number of units of analysis in each group's behaviour and how it was observed per group. With both groups, these results showed that exchanging information was the most noticeable interactive behaviour, which is one of the Jigsaw cooperative learning characteristics. Data reflected that the treatment group exchanged more information during group discussions (treatment group $=22.0 \%$ vs control group $=16.5$ ). As regards the data in Question 7, the treatment group demonstrated twice as much interaction per group activity $(21.0 \%$ vs $18.5 \%)$ than the control group. The control group only showed a better score in Question 6, which reflected the degree to which they received feedback and support from facilitator ( $8.0 \%$ vs 10.0\%).

\subsection{Teachers perceived interactions in the group learning activities}

Table 4 summarises the results regarding treatment group and control group perceptions on the quality of interactions among participants during the learning activities.

Table 4: Teachers perceived interactions in the group learning activities $(n=267)$

\begin{tabular}{|c|c|c|c|c|c|c|}
\hline & Question statement & Group type & $S A \& A(\%)$ & $\mathrm{D} \& \mathrm{SD}(\%)$ & Mean & t-value \\
\hline \multirow{2}{*}{8} & \multirow{2}{*}{ I/We had goodinteractions with other members in our group } & Expert group & 97 & 3 & 3.9 & $3.67^{\star \star}$ \\
\hline & & Control group & 69 & 31 & 3.0 & \\
\hline \multirow{2}{*}{9} & \multirow{2}{*}{ I/We had good interactions with the facilitator in our group } & Expert group & 81 & 19 & 3.6 & $2.79 * \star$ \\
\hline & & Control group & 68 & 32 & 2.4 & \\
\hline \multirow{2}{*}{10} & \multirow{2}{*}{$\begin{array}{l}\text { I/We like to work together with my/our group members } \\
\text { usingeconomics concepts }\end{array}$} & Expert group & 88 & 12 & 3.6 & $2.77^{\star \star}$ \\
\hline & & Control group & 74 & 26 & 3.0 & \\
\hline \multirow{2}{*}{11} & \multirow{2}{*}{$\begin{array}{l}\text { I/We built good relationships and could depend on each other to } \\
\text { succeed in our group activities }\end{array}$} & Expert group & 90 & 10 & 3.7 & $2.10^{*}$ \\
\hline & & Control group & 67 & 33 & 2.9 & \\
\hline
\end{tabular}

${ }^{*} \mathrm{p}<0.05 ;{ }^{* \star} \mathrm{p}<0.01 \quad$ Scale: $\mathrm{SA}=$ Strongly agree, $A=A g r e e, D=$ Disagree, $\mathrm{SD}=$ Strongly disagree

Table 4 presents data regarding teachers' perceived interactions with each other while participating in economics activities. The expert group perceived better group interactions with their peers during group learning (Question 8, 
$t(100)=3.67, P<0.01$; Question 9, $t(100=2.79, P<0.01$ and Question 10, $t(100)=2.77, P 0.01)$ as compared to the normal group. Ninety-seven percent of the expert group agreed that they had good interactions with other members in their groups, as well with facilitators (81\%). They also said that they liked working with their group members (88\%) using economics concepts (Question 8 and 9, SA \& A).

Teachers in the expert group exchanged ideas and engaged in interactions with their group members more consistently as compared to the control group. In Question 11, $t(100) 2.1, P=0.05$, the expert group indicated that they had built good relationships and could depend on each other to succeed in their group activities (90\%) in the group learning activities.

\subsection{Classroom observations during ToT project activities}

It was observed that teachers in the different group sessions always used mind maps to exchange concept ideas with fellow team members while participating in the selected expert group. Group dynamics clearly show that members shared ideas, agreed and work collaboratively to achieve specific objectives for the task; as a result, positive interdependences were created within expert groups.

It was also observed that the expert group exchanged excellent ideas regarding the structuring of different economics mind maps. During the overall group presentations, the treatment groups were easily able to obtain and review other groups' mind maps. Members of the treatment groups gave more constructive feedback to and received more constructive feedback from other members of the group, resulting in more effective interactions during group discussions.

A photocopying machine, four laptops and internet usage were made available to each group for use while exchanging mind maps or information relating to their lesson presentation. An "ice-breaker" was used by session facilitators to trigger interest for group discussions for specific topics for example-poverty in the community at the beginning of each unit of the workshops.

It was observed that teachers began conversations by exchanging ideas on their mind maps and other information. Groups presented their concept maps covering several contemporary economic topics that had been facilitated during the ToT sessions. Mind maps were pasted on the classroom boards and walls, allowing other groups to observe each group mind map structure. The ability to share their mind maps instantaneously with others was motivating, enabling teachers to receive almost immediate feedback on their mind maps. In addition, teachers became more involved in their own groups' task because they were able to compare other groups' concept mind maps with their own, It was further observed that group competition occurred on several occasions.

\section{Discussion of Results}

The results of this study indicate that there were significant differences between the expert group as compared to the control group as regards the pretest-posttest scores (EMT \& AET) of two data collection instruments. This suggests that teachers exposed to the ToT initiative performed better in economic literacy, positive attitude toward economics and experienced an increase in understanding economics as a discipline. We can therefore conclude that the ToT initiative impacted significantly on teachers' learning in economics education. Moreover, classroom observations showed that economics teacherswho participated in the project were more engaged, sharing ideas, receiving immediate feedback on their presentations and were highly motivated during the learning activities. Van Wyk (2012) conducted a similar study which concurred with the findings of this study that showed the ToT initiative is an effective, powerful and applicable empowerment project to advance economics education in FSDoE schools.

The results of this study are consistent with student reactions to cooperative learning groups discussed by other researchers (Van Wyk, 2010, Yamarik 2007; Vaughan 2002). Previous studies conducted indicated that students in the cooperative learning group showed greater academic achievements and knowledge retention than those in the control group (Tran and Lewis, 2012; Soodak and Podell, 1994; Van Wyk, 2010; Ghaith \& Shaaban, 1999). In the present study, the teachers in the expert group reported more effective learning in groups, more helpfulness and mutual teaching, more discussion of the learning material among participants and a greater level of information exchange than they had experienced in traditional teacher-centered classrooms.

In this study, classroom observations during the ToT project also encompassed the social benefits of cooperative learning identified by Johnson (2003). Findings of latter study revealed that students in the treatment group recognized that that there was more mutual concern among students when they worked together in a cooperative learning group. They believed that each member was responsible not only for his or her own learning but also for others' learning to 
achieve the shared goals of the group.

Research has shown that interactions during expert group work may occur in a variety of ways, such as exchanging resources/information, giving/receiving help/feedback, and challenging and encouraging other students (Van Wyk, 2012; Yamarik 2007). During this study it was observed that teachers always exchanged concept ideas in mind maps with team members when participating in the selected expert group. It was also observed that participants really supported and exchanged each other's ideas regarding the structuring of different mind maps.

The present study appears to support Johnson and Johnson's (2009) findings that achievement and attitudes in the cooperative learning context are strongly correlated. Specifically, this ToT initiative spur teachers to greater levels of achievement, which in turn had a positive impact on their attitudes to teaching. The results of this study concur with previous studies that show that teachers' ability to share their work instantaneously with other teachers in the expert group is motivating because it allows them to receive almost instant feedback on their work (van Wyk, 2012; Coladarci 1992,).

\section{Concluding Remarks}

Results indicated that there are significant differences between the pretest-posttest scores of the expert group as compared to the control group. This implies that teachers exposed to the ToT project performed better in the all the posttest scores.

Classroom observations showed that expert economics teachers in the sessions group were more engaged, sharing ideas, receiving immediate feedback on their presentations and were highly motivated in the learning activities.

It was observed that teachers used mind maps and group discussions to exchange concept ideas with team members during the selected expert group. It was further observed that the expert group was supportive of the exchange of ideas in different mind maps.

\section{Recommendations For Further Research}

The findings of the present study indicate the positive effects of Training-of-Trainers project on economics teachers' attitudes toward their own learning, as well as towards the subject. However, it is difficult to demonstrate a generalisable effect on teacher attitudes from a short period of training, such as that reported in this research study. In addition, attitudes are both abstract and subjective, and it is therefore difficult to measure changes in attitude over a short time.

One must view the present study cautiouslybecause of four limitations. The first limitationconcerns the sample size which involved a small number of ToT teachers $(n=267)$ who participated in this study.Because of the restricted range of participants,in future research studies, the researcher should include a more diverse and representative sample ofteachers and learners. The second limitation is the time factor. This study was conducted onlyon a fourteen day workshop. A longer investigationperiod will maybe yield different results. The thirdlimitation is economics subject knowledge andpedagogical knowledge. This was a seriousconcern for some teachers because of limited orlack of knowledge regarding pre-course economicscontent and different teaching strategies. This impeded a lot on how to learn the subjectand how to implement applicable teachingstrategies to enhance their praxis.

The following recommendations are formulated to advance economics education in South Africa beyond the $21^{\text {st }}$ century;

- Develop partnerships with professional associations and corporate business;

- Coordinate teacher workshops, co-presented by professional teachers and economists in all nine provincial departments of education;

- Plan bi-annual conferences where economics teachers can network and learn how to improve economic, financial and entrepreneurial literacy.

- Provide innovation and leadership awards to teachers to recognize excellence in economic education;

- Develop endorsed short courses for economics teachers to meet the new Continuing Professional Teacher Development criteria;

- Develop after-school activities, such as the development of entrepreneurial skills;

- Organize a speaker's programme where business and community leaders go to schools to discuss certain economic issues;

- Researching on a national level economics education in South African schools to advance the quality of teaching and learning of the subject; 
- Establishment of a South African Journal of Economic and Financial education by publishing research papers and best classroom based practices;

- Develop community mentorship program for empowering the youth with the financial knowledge and skills to start businesses; and

- Plan and establish virtual centres of economics education at higher education institutions

\section{Acknowledgement}

I am indebted to Prof Klopper Oosthuizen, the critical reviewer for constructive feedback on this lecture. Acknowledgements are due to SAFEFE staff (in particular Mrs Ina Combrick) the Training-of-Trainers facilitators, economics teachers, language editing coordinator and the research assistant, who voluntarily participated in this research study as part of this inaugural lecture. I also acknowledge the financial contributions made by the National Research Foundation of South Africa (NRF) for the grant funding (ID.76348) Ref No: TK 2008043000005. Any opinions, findings, and conclusions expressed in this lecture are those of the author and do not reflect the views of the NRF or the Department of Curriculum and Instructional Studies, College of Education.

\section{References}

Alexander.G, van Wyk. MM, Bereng T \& November,IP. The Legitimation of Recognition of Prior Learning as Redress Mechanism for work in Post-Apartheid South Africa: Narrative of a Black Master Builder. Journal of Social Science, 26(2): 153-162 (2011)

Aronson E 2005. Jigsaw classroom. Available at: http://www.jigsaw.org. (Retrieved October 29, 2011).

Bandura, A. 1997. Self-efficacy: The exercise of control. New York: Freeman.

Cohen L, Manion L, Morrison K 2009. Research methods in education. $6^{\text {th }}$ Edition.London: Routledge Farmer.

Coladarci T 1992. Teachers' sense of efficacy and commitment to teaching. Journal of Experimental Education, 60(4): 323-337.

Darling-Hammond, L., \& Bransford, J. (2005). (Eds.). Preparing teachers for a changing world: What teachers should learn and be able to do. San Francisco: Jossey-Bass.

Department of Basic Education (DBoE). 2010. Curriculum and Assessment Policy Statement (CAPS) Department of Basic Education. Government Press: Pretoria.

Dickie M 2006.Do classroom experiments increase learning in introductory microeconomics? Journal of Economic Education, 37: 267288.

Ghaith G, Shaaban K 1999. The relationship between perceptions of teaching concerns, teacher efficacy, and selected teacher characteristics. Teaching and Teacher Education, 15: 487-496.

Goddard RD, Hoy, WK, Woolfolk WK, Hoy A 2000. Collective teacher efficacy: Its meaning, measure, and impact on student achievement. American Educational Research Journal, 37: 479-507.

Ghaith G, Yaghi H 1997. Relationships among experience, teacher efficacy, and attitudes toward the implementation of instructional innovation. Teaching and Teacher Education, 13: 451-458.

Gao, L. (1992). The generative style of teaching: Rationale and practice. Paper presented at the meeting of the ICTPE, Dortmund, Germany.

Gao, L., Adcock, H., Carr, M., Hume, A., Nicholson, D., Silvester, J., et al. (1989). An account of action research investigating teacher change. Research in Science Education, 19(1), 112e122. doi:10.1007/BF02356851.

Gao, L., \& Watkins, D. A. (2002). Conceptions of teaching held by school science teachers in P.R. China: identification and cross-cultural comparisons. Science Education, 24(1), 61e79. doi:10.1080/09500690110066926.

Johnson DW 2003. Social interdependence: Interrelationships among theory, research, and practice. American Psychologist, 58, 934945.

Lave J, Wenger E 1991. Situated learning: Legitimate peripheral participation. New York: Cambridge University Press.

Lewis, L., Parsad, B., Carey, N., Bartfai, N., Farris, E., \& Smerdon, B. (1999). Teacher quality: A report on the preparation and qualifications of public school teachers.Education Statistics Quarterly, 1(1) http://nces.ed.gov/programs/quarterly/Vol_1/1_1/2esq11-a.asp (Retrieved 14 February 2013)

Mezirow, J.1991.Transformative Dimensions of Adult Learning. San Francisco: Jossey-Bass

Mezirow, J. (1996) Contemporary Paradigms of Learning Adult Education Quarterly, 46, 158-172.

Midgley C, Feldlaufer H, Eccles J 1989. Change in teacher efficacy and student self- and task-related beliefs in mathematics during the transition to junior high school. Journal of Educational Psychology, 81: 247-258.

National Department of Education. 1997. Norms and Standards for Educators policy document Pretoria: Government Press

National Council on Economics Education 2005. Train the Trainers Programme 2005-2007: Seminars A,B, C and D. Economics International. New York.

National Policy Framework for Teacher Education and Development in South Africa (National Department of Education 2007),

National Department of Education 2003. National Strategy for Further Education and Training: Policy. Pretoria: Government Press.

Shiller RJ. 2010. How Should the Financial Crisis Change How We Teach Economics? The Journal of Economic Education, 41(4): 403- 
409. http://dx.doi.org/10.1080/00220485.2010.510409 (Retrieved 12 March 2013)

Soodak LC, Podell DM 1994. Efficacy and experience: Perceptions of efficacy among pre-service and practicing teachers. Journal of Research and Development in Education, 30(4): 214-221.

Tschannen-Moran M, Woolfolk Hoy A 2001. Teacher efficacy: Capturing and elusive construct. Teaching and Teacher Education, 17: $783-805$.

Vaughan W 2002. Effects of Cooperative Learning on Achievement and Attitude Among Students of Color.The Journal of Educational Research. 95(6): 359-364.

Van Wyk MM 2012. Effectiveness of the Training of Teachers project in Economics education in Free State secondary schools. Journal of Social Science, 30(3):243-250

Van Wyk, MM and G Alexander.2010. Do Teaching Methods Presented by the National Council on Economics Education (USA) Enhance Trainers' Learning Capacity in Economics Education? A South African Perspective.Journal of Social Science, 23(3): 159-169

Van Wyk MM, Alexander G \& Moreeng BB. 2010. Education as Transformation: A case of a Faculty. South African Journal for Higher Education, 24(6): 1036-1051

Van Wyk MM 2007. The Use of Cooperative Learning in the Further Education and Training Phase in the Free State Province. Ph.D. Thesis, Unpublished. Bloemfontein: University of the Free State.

Walstad WB 1997. "Effectiveness of a USMES In-Service Economics education Program for Elementary School Teachers," Journal of Economics education, 11(1):1-12.

Walstad WB 1992. Economics instruction in high schools. Journal of Economic Literature, 30(2):19-51.

Walstad WB, Rebeck K 2001.Teacher and student economic understanding in transition economies. Journal of Economic Education, 3(2): 57-67)

Wheatley KF 2005. The case for reconceptualising teacher efficacy research. Teaching and Teacher Education, 21: 747-766. 
